OPEN ACCESS

Citation: Isau Huamantupa-Chuquimaco (2020) Vochysiatepuiandina(Vochysiaceae), a new species from the sub Andean Cordillera forests. Webbia. Journal of Plant Taxonomy and Geography 75(2): 237-242. doi: 10.36253/jopt8999

Received: June 6, 2020

Accepted: July 12, 2020

Published: November 18, 2020

Copyright: () 2020 Isau HuamantupaChuquimaco. This is an open access, peer-reviewed article published by Firenze University Press (http://www. fupress.com/webbia) and distributed under the terms of the Creative Commons Attribution License, which permits unrestricted use, distribution, and reproduction in any medium, provided the original author and source are credited.

Data Availability Statement: All relevant data are within the paper and its Supporting Information files.

Competing Interests: The Author(s) declare(s) no conflict of interest.

Editor: Piero Delprete

\section{Vochysia tepuiandina (Vochysiaceae), a new species from the sub Andean Cordillera forests}

\author{
IsAu HuAmantupa-Chuquimaco \\ Herbario (CUZ), Universidad Nacional de San Antonio Abad del Cusco (UNSAAC), Av. \\ de la Cultura 733, Cusco, Perú \\ Programa de Pós-Graduação em Botânica, Escola Nacional de Botânica Tropical, Insti- \\ tuto de Pesquisas Jardim Botânico do Rio de Janeiro (ENBT/JBRJ). 22460-030, Rua \\ Pacheco Leão, 915, Rio de Janeiro, Brazil \\ Centro Ecológico INKAMAZONIA, Valle de Kosñipata, via Cusco, PN Manú, Cusco, Perú \\ E-mail: andeanwayna@gmail.com
}

Abstract. Vochysia tepuiandina is here described and illustrated. It occurs in southern Ecuador and northern Peru, and is associated with the disjunct "Andean Tepuis" forests found within the Andean piedmont and of the Amazonian forests. This species is placed in the Vochysia section Ciliantha subsection Ferrugineae. It is compared with the similar species $V$. angustifolia and V. sprucei.

Keywords: disjunt, diversity, Vochysia sect. Ferrugineae, Andean tepuis.

\section{INTRODUCTION}

The arboreal genus Vochysia Aubl. (Vochysiaceae) is widely distributed in Neotropical forests from Mexico to Paraguay, with more than 145 species, of which more than $60 \%$ is found in Amazon forests (Marcano-Berti 2013; Huamantupa-Chuquimaco 2017). Within Vochysia 4 sections are recognized: Apopetala, Ciliantha, Pachyantha and Vochysiella (Stafleu 1948; Marcano-Berti 2013), within the Ciliantha section, the Ferrugineae sub section is one of the most diverse with 29 species (Huamantupa-Chuquimaco 2017). The Amazon forests located at the Andean piedmont are recognized worldwide as diversity hotspots. They occur in several countries including Bolivia, Colombia, Ecuador and Peru (Myers et al. 2000). These areas integrate as well with sub-Andean mountain ranges where disjoint formations known as Andean Tepuis are found. These forests are associated mainly with white-sand soils, which has been hypothesized to be related to the Tepuis of the Guyana Shield (Neill et al. 2007). They are distributed mainly in Colombia, Ecuador and Peru. The ones located in Ecuador are part of the Cordillera del Kutuku whereas in Peru they distribute along the cordilleras del Cóndor, Escalera, Kampankis and Azul (Neill et al. 2012, 2014). These areas have been described as biologically rich and with high endemism (Neill et al. 
2014; Huamantupa-Chuquimaco and Neill 2018). Is in this region where the new species Vochysia described in this document occurs.

\section{MATERIALS AND METHODS}

The specimens examined were collected as a product of different collaborative projects. These projects include botanical and ecological collections on the Andean and Amazon forests in Ecuador and Peru, such as the permanent plots monitored by RAINFOR, the Missouri Botanical Garden-Perú (MBG) and others. The fertile specimens were analyzed in the HOXA, MO, NY and USM herbaria (acronyms according to Thiers 2019).

The morphological terminology follows the specialized literature of Stafleu (1948) and Marcano-Berti (2014), complemented with specific terminologies from Payne (1978), Font Quer (1989), Beentje et al. (2001), Schmid et al. (2002), and Ellis et al. (2009).

The species conservation status was assessed using GeoCat software (http://geocat.kew.org; Bachman et al. 2011), following IUCN (2017) criteria. Species distribution maps were prepared with ArcGIS 10.2 (ESRI 2013 Vochysia tepuiandina Huamantupa).

\section{TAXONOMIC TREATMENT}

Vochysia tepuiandina Huamantupa, sp. nov. (Figures 1, 2).

Type: Ecuador, Zamora-Chinchipe, Yantzaza, Región de la Cordillera del Cóndor, Cuenca del Río Machinaza, Campamento las Peñas, Parcela 5, 03ํำ' $078^{\circ} 29^{\prime} \mathrm{W}-$ 03ํำ' $078^{\circ} 30^{\prime} \mathrm{W}, 1400-1840 \mathrm{~m}, 24$ Nov. 2008 (fl.), $W$. Quizhpe, F. Tello, B. Medina, W. Zeas \& L. Andrade 3237 (holotype, QCNE!; isotype, MO!).

\section{Diagnosis}

This species has leaves with 11-15 secondary veins on each side of the midrib, leaf apex acuminate, cincinni 1-2 (generally 1), indumentum of sepals and petals tomentose, staminodes absent; it differs from T. angustifolia, which has 30-40 secondary veins on each side of midrib, obtuse or retuse leaf apex, 2-3 cincinni, and sepals and petals glabrous, and staminodes $0.5-1.0 \mathrm{~cm}$ long.

\section{Description}

Tree to $30 \mathrm{~m}$ tall. Stem sub terete, quadrangular, scabrous; young branches with distal internodes densely tomentulose, hairs dark brown. Stipule deltoid-triangular, $1.3-1.6 \times 1.0-1.3 \mathrm{~mm}$, tomentose. Leaves opposite; petioles $0.5-1.2 \mathrm{~cm}$ long, $1.5-2.3 \mathrm{~mm}$ diameter at base, subterete, slightly canaliculated, scabrous to densely villose in young leaves; blades lanceolate, oblong-elliptic, elliptic, $3.1-10.1 \times 1.0-3.1 \mathrm{~cm}$, acute at base; acuminate at apex; acumen $0.6-1.0 \mathrm{~cm}$ long; adaxial surface glabrous to sparsely scabrous, when present the sparcely hairs are more expressed on the veins; abaxial surface scabrous in old leaves, densely and minutely tomentosevillose in young leaves, hairs white-brown, ca. $0.15 \mathrm{~mm}$ long; coriaceous; venation pinnate; midvein impressed and conspicuous on the abaxial surface; secondary veins 8-15 on each side of midrib, impressed on adaxial surface and slightly prominent on the abaxial surface; tertiary veins slightly impressed on the adaxial surface and slightly prominent on the abaxial surface, brochidodromous. Inflorescence terminal, sometimes also axillary; thrysoid, 3-7 cm long, densiflorus, erect, main axis densely tomentulose, tomentose, with reddish brown hairs; a compound raceme with cincinni most frequently uniflorous, or 1-2-flowered; peduncles 4-7.1 mm, densely tomentulose. Pedicels $2.5-3 \mathrm{~mm}$ long, densely tomentose. Flower buds elongate, slightly recurved, navicular, 5-8 $\mathrm{mm}$ long, round at apex, densely pilose-tomentose; 1-2 bracteoles, subulate ca. $2.0-2.5 \mathrm{~mm}$ long, densely tomentose. Flowers orange-yellow, together with the spurred sepal $0.9-1.2 \mathrm{~cm}$ long, nearly straight to navicular; spur terete, straight no curved, apex rounded, 1-1.5 $\times 0.8-1.0 \mathrm{~mm}$, forming an angle of $80-90^{\circ}$ with the pedicel, densely tomentose; dorsal sepal $6-6.5 \times 2.8-3.1 \mathrm{~mm}$, outer surface densely tomentose, inner surface glabrous with the border ciliate; smaller sepals oblong-deltoid, $1.9-2.1 \times 1.7-1.9 \mathrm{~mm}$, outer surface densely tomentose, inner surface sparsely tomentulose; petals 3 , unequal, oblong-lanceolate, oblong, the larger and central petal 2.5-3.5 × 1-1.7 mm, outer surface densely brownreddish tomentose, more dense in the apex, hairs ca. $1.5 \mathrm{~mm}$ long; the 2 smaller petals with the same shape, $1.9-2.5 \times 1.2-1.9 \mathrm{~mm}$, outer surface scabrous, with some hairs in the base and middle vein, inner surface glabrous, border ciliate, hairs ca. 0.7-0.8 mm long. Stamens $6.5-7.1 \mathrm{~mm}$ long, straight to slightly curved; filaments $0.5-0.6 \mathrm{~mm}$, sparsely ciliate-tomentulose in the base; anthers 5.5-6.5 mm long, conduplicate, slightly incurved to navicular, each side of the anther $\pm 0.8 \mathrm{~mm}$ long, ciliate-tomentulose, more dense in the borders, glabrous on the apex. Staminodes unknown. Ovary glabrous, 0.7$1.0 \mathrm{~mm}$ long; style $4.6-5.0 \mathrm{~mm}$ long; stigma terminal, slightly capitate-sagitate. Fruit unknown.

\section{Etymology}

The epithet "tepuiandina" is named after the habitat in the "Andean Tepuis" from the sub Andean cordilleras 


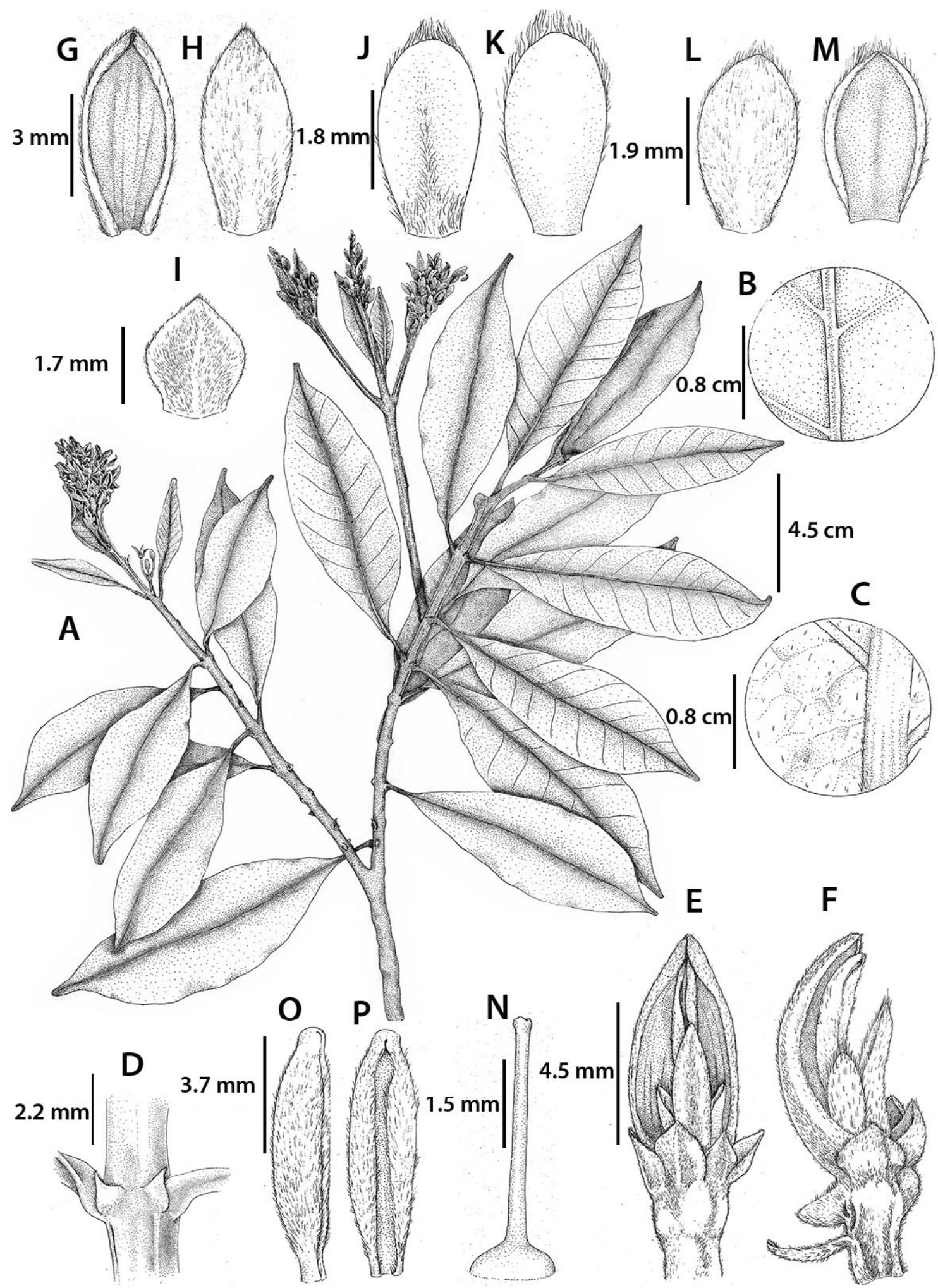

Figure 1. Vochysia tepuiandina. A. Habit with inflorescence, B. Leaf adaxial surface (close-up), C. Leaf abaxial surface (close-up), D. Stipule, E. Flower, front view, showing petals and sepals, F. Flower, lateral view. G, H. Dorsal sepal, internal and external surface, I. Smaller sepal, J, K. Large petal internal and external surface, L, M. Smaller petals, N. Ovary and style, O. Anther and P. Anther. Illustration by N. Sánchez, from W. Quizhpe \& al. 3237. 


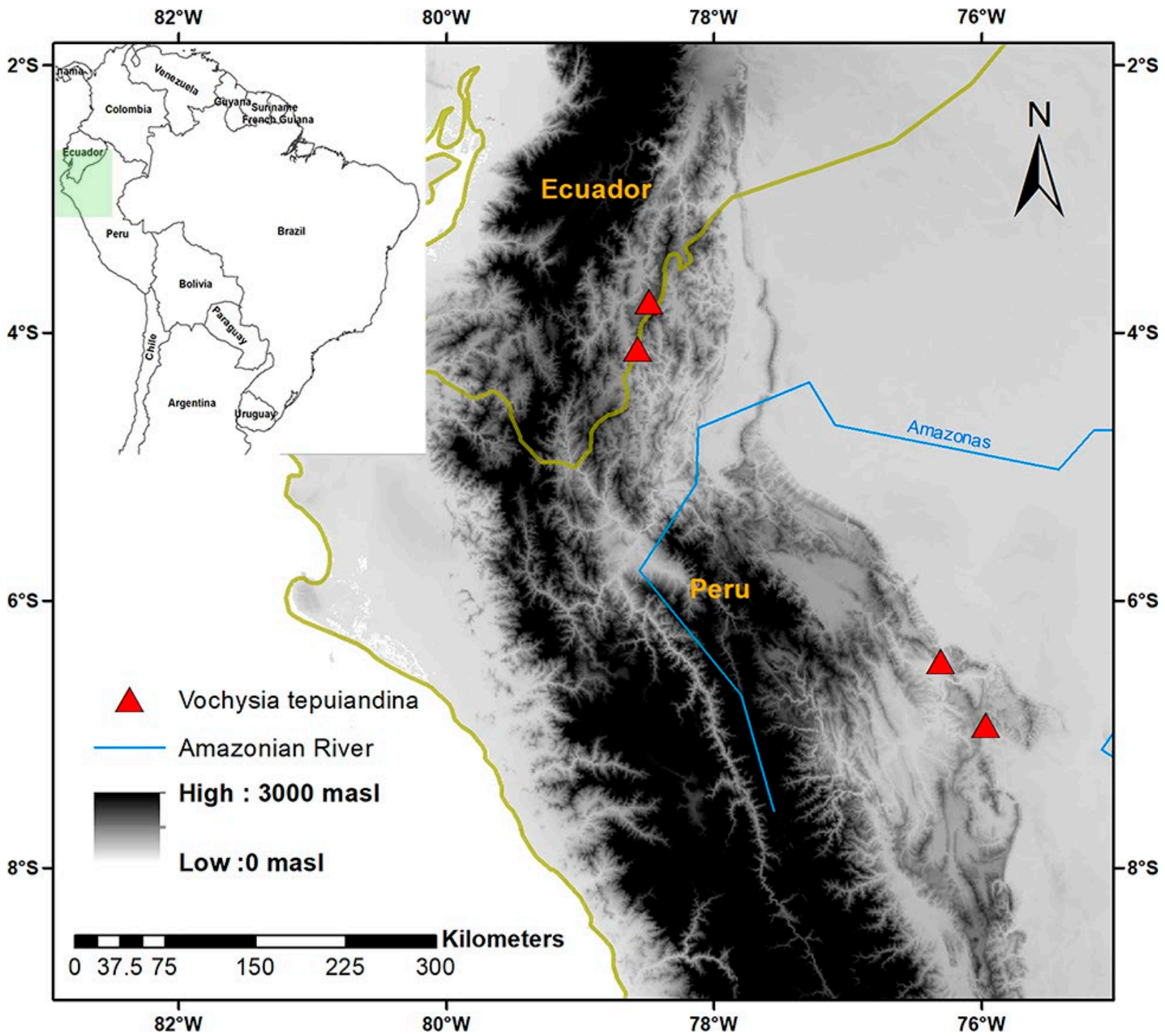

Figure 2. Geographic distribution of Vochysia tepuiandina (A) in the sub Andean mountains (Andean tepuis) in Ecuador and Peru.

preferred by this species. These habitats have quarzitic stone formations similar to the Tepuis of the Guiana Shield, distributed along mountain ranges between the north-central of Peru to southern Ecuador.

\section{Distribution and ecology}

Vochysia tepuiandina is known from the "Andean Tepuis" group of disjunct mountains associated to sandy outcrops related to Guiana Shield Tepuis ranging from Venezuela and Guyana, in Ecuador and Peru, This mountain region is distributed and interconnected from the southern of Ecuador to northern Peru, belonging to what is known as Cordillera del Condor, then continues to Cordillera Azul and Cerro Escalera in Loreto and San Martin region in the northern Peru. The altitudes range between 1240 and $1840 \mathrm{~m}$ above sea level.

\section{Phenology}

Flowering specimens were collected between October and December.

\section{Conservation status}

Vochysia tepuiandina is only known from the Cordillera del Cóndor, Cordillera Azul and Cordillera Escalera and in the surroundings of these areas, a region 
Table 1. Characters separating Vochysia tepuiandina from V. angustifolia and V. sprucei.

\begin{tabular}{lccc}
\hline Character & V. tepuiandina & V. angustifolia & V. sprucei \\
\hline $\begin{array}{l}\text { Number of secondary veins on } \\
\text { each side of midrib }\end{array}$ & $11-15$ & $30-40$ & $16-24$ \\
$\begin{array}{l}\text { Indumentum on leaf abaxial } \\
\text { surface }\end{array}$ & glabrous & glabrous & $\begin{array}{c}\text { sparcely stiff-ferrugineous, with } \\
\text { brown-orange puberulence }\end{array}$ \\
$\begin{array}{l}\text { Leaf apex } \\
\text { Inflorescence length }\end{array}$ & acuminate & obtuse, retuse \\
Number flowers in cincinni & $3-7 \mathrm{~cm}$ & $8-14 \mathrm{~cm}$ & $7-12 \mathrm{~cm}$ \\
Sepals indumentum & $1(-2)$ & $2-3$ & $2-3$ \\
Spur shape and dimensions & tomentose & glabrous & glabrous \\
Petal indumentum in the outer & globose, $1.0-1.5 \times 0.8-1 \mathrm{~mm}$ & elongated, $6.0-8.0 \times 1-1.2 \mathrm{~mm}$ & elongated, $5.0-6.0 \times 1.0-1.2 \mathrm{~mm}$ \\
surface & tomentose & glabrous & glabrous \\
Staminodes & absent & $0.5-1.0 \mathrm{~cm}$ long & $1.0-1.5 \mathrm{~cm} \mathrm{long}$ \\
\hline
\end{tabular}

that is part of southern Ecuador and continuing to northern Peru. Based on the IUCN (2017) criteria and it geographic distribution, which was calculated using the Geocat Software (2017), the extent of occurrence (EOO) of $V$. tepuiandina is $7,966 \mathrm{~km}^{2}$ and its area of occupancy is $16 \mathrm{~km}^{2}$, therefore this species, according to IUCN (2017) standards is classified as Endangered (EN).

\section{Remarks}

Vochysia tepuiandina belongs to Vochysia sect. Ciliantha subsect. ferrugineae. All the species of this group are characterized principally by brown stems and bark, sometimes exfoliating, stipules always present, leaves in whorls or opposite, young branches and leaves ferruginous-pilose on the abaxial face, inflorescences terminal and sometimes axillary, flowers with 3 petals, rarely one, petals and stamen pilose-ciliate along the margins and base, style and glabrous ovary (Stafleu 1948). Therefore, Vochysia tepuiandina can be differentiated from $V$. angustifolia Ducke (1932). The latter species is a medium-sized tree, to $15 \mathrm{~m}$ tall, with lanceolate stipules, leaf blades with more of 30 secondary veins on each side of midrib, clearly glabrous on the abaxial surface, cincinni with 2-3 flowes, and sepal and petals are glabrous; and is commonly restricted to seasonally inundated forests, river banks in the Rio Negro and Amazonas basin. On the other hand, Vochysia tepuiandina is markedly a large tree up to $30 \mathrm{~m}$ tall, with leaf blades with less than 15 secondary veins on each side of midrib, cincinni with 1-2 flowers, and sepals and petals densely tomentose. It is more commonly distributed in montane forests associated to poor sandy soils. Another similar specie is Vochysia sprucei Warming (1875), which is described from the Cerro Pelado mountains in Tarapoto province, relatively close to Cerro Escalera, Peru; it dif- fers from $T$. tepuiandina by the leaves that are sparsely stiff-ferruginous and with brown-orange puberulence on the abaxial surface, with more of 16 secondary veins on each side of midrib, obtuse at apex, sepals and petals glabrous, and presence of staminodes. A comparison of morphological characters of these three species is presented in Table 1.

\section{Specimens Examined}

ECUADOR: Zamora-Chinchipe: Yantzaza. 03ํำ' 78²9'W, 1400-1840 m, 12 Oct. 2008, W. Quizhpe \& al. 3142 (QCNE, MO); Nangaritza, Faldas de la Cordillera del Cóndor. 0407'S 078³4'W, 1600-1680 m, 5 Dec. 1990, W. A. Palacios \& D. A. Neill 6535 (QCNE, MO). PERÚ: Loreto: Ucayali, Pampa Hermosa. Parque Nacional Cordillera Azul, 655'41.80”S 7557'56.20”W, 1497 m, 26 Mar. 2018, Y. Soto \& al. 1159 (HOXA). San Martín: Tarapoto, Cordillera Escalera, Bosque de tierra firme, 6²7'7.54"S, 76²18'0.49”W, 1256 m, 6 Feb. 2017, H. Flores, \& H. Vásquez $1352(\mathrm{HH})$.

\section{ACKNOWLEDGMENTS}

I wish to thank to Dr. Olga M. Monthiel for providing invaluable support and facilities during a visit to MO herbarium, Drs. Ron Liesner and Daniel Santamaria for their support during my visit to MO herbarium. Rodolfo Vázquez and Rocio Rojas, herbarium curator and research associate, kindly permitted access to their collections in Peru at the HOXA herbarium. I thank also Nidia Sánchez for her line drawing of the new species. Thanks go to our biology colleagues Euridice Honorio and Timothy Baker for the invitation to workshop in the Oxapampa city, where was described some paratypes of 
V. tepuiandina. Special thanks go to Roosevelt García by the review the manuscript and the English text.

\section{REFERENCES}

Aublet J. B. C. 1775 . Histoire des Plantes de la Guiane Françoise, vol. 1: 372-374.

Bachman S, Moat J, Hill AW, de la Torre J, Scott B. 2011. Supporting Red List threat assessments with GeoCAT: Geospatial conservation assessment tool. ZooKeys. 150: 117-126.

Beentje H, Hickey M, King C. 2001. The Cambridge Illustrated Glossary of Botanical Terms. Kew Bulletin. https://doi.org/10.2307/4110976.

Ducke A. 1932. Bull Mus Nat His Par. 1932. Ser. II IV. Pp. 738.

Ellis B, Daly DC, Hickey LJ, Mitchell J. D, Johnson KR, Wilf SL. 2009. Manual of leaf architecture. New York: Cornell University Press, Ithaca.

ESRI 2013. ArcGIS Desktop: Release 10.2. Redlands $C A$.

Font Quer P. 1989. Diccionario de botánica. 1244 pp. Labor, Barcelona.

Huamantupa-Chuquimaco I. 2017: Vochysia peruviana (Vochysiaceae), a new species from Flooded Forests, Madre de Dios Peru. Phytotaxa. 306 (4): 275-280.

Huamantupa-Chuquimaco I, Neill DA, 2018. Vochysia condorensis (Vochysiaceae), a new species from the cordillera del cóndor, Ecuador. Phytotaxa. 340 (1): 079-085.

Marcano-Berti L. 2014. Apopetala, una nueva sección de Vochysia (Vochysiaceae). Pittieria. 38: 15-42.

Myers N, Mittermeler RA, Mittermeler CG, Da Fonseca GA, Kent J. 2000. Biodiversity hotspots for conservation priorities. Nature 403:853-858.

Neill D, Huamantupa I, Kajekai C, Pitman N. 2012. Vegetación y flora/Vegetation and flora. - Pp. 87-96 and 242-250 in: Pitman N., Ruelas E., Alvira I., Vriesendorp C., Moskovits D. K., del Campo Á., Wachter T., Stotz D. F., Noningo S. S., Tuesta C. E. \& Smith R. C. (ed.) Perú: Cerros de Kampankis. Rapid Biological and Social Inventories Report 24. The Field Museum, Chicago.

Neill DA. 2007. Floristic inventory of the Cordillera del Cóndor, Ecuador and Peru. Available from: http:// www.mobot.org/MOBOT/ Research/ecuador/cordillera/welcome.shtml (accessed 7 December 2018).

Neill DA, Ríos PM, Torres MLA, Mori VTJ, Vriesendorp C. 2014. Vegetación y Flora/Vegetation and flora. Pp. 292-311 In: Pitman N, Vriesendorp C, Alvira D, Markel JA, Johnston M, Ruelas IE, Lancha PA, Sarmiento VG, Álvarez-Loayza, P, Homan J, Wachter T, del Campo Á., Stotz DF, Heilpern, S. (ed.). Peru: Cordillera Escalera-Loreto. Rapid Biological and Social Inventories Report 26. The Field Museum, Chicago.

Payne WW. 1978. A Glossary of Plant Hair Terminology. Brittonia. 30: 239-255.

Schmid R, Harris JG, Harris MW. 2002. Plant Identification Terminology: An Illustrated Glossary. https:// doi.org/10.2307/1554893.

Stafleu FA.1948. A monograph of the Vochysiaceae. I. Salvertia and Vochysia. Recueil Acta Botanica Neerlandica. 41. 398-540.

Theobald WL, Krahulik JL, Rollings CR. 1979. Trichome description and classification. Pp. 0-53 in: Metcalfe L. \& Chalk C. (eds), Anatomy of the dicotyledons. Oxford.

Thiers BM. 2019. Index Herbariorum: A Global Directory of Public Herbaria and Associated Staff. New York Botanical Garden's Virtual Herbarium. http://sweetgum.nybg.org/ih/.

Warming, E. 1875. Vochysiaceae in: Flora Brasiliensis. 13(2): 99. 